Vol. 4, No. 4, 2019

\title{
ANALYSIS OF THE ENVIRONMENTAL IMPACT OF UNSORTED CULLET
}

\section{Larysa Hurets, Anastasiia Kotolevets, Hanna Miakaieva, Oleksandr Miakaiev}

\author{
Sumy State University, \\ 2, Rymskogo-Korsakova Str., Sumy, 40007, Ukraine \\ larisagurets@gmail.com
}

https://doi.org/10.23939/ep2019.04.191

Received: 24.09 .2019

(C) Hurets L., Kotolevets A., Miakaieva H., Miakaiev O., 2019

\begin{abstract}
Prediction of cullet accumulation at municipal solid waste landfills was carried out by linear and multiple regression methods. Over time, the amount of waste at the landfills will increase and the soil condition will deteriorate due to $\mathrm{Na}^{+}$leaching This is confirmed by the experimental study of leaching of sodium ions from the cullet surface of different fractions with pure water and solutions with $\mathrm{pH}=4.8$ and $\mathrm{pH}=9.2$.
\end{abstract}

Key words: glass cullet, waste management, mathematical model, leaching, glass dispersity, sodium ions.

\section{Introduction}

Global technological progress has naturally led to the fact that human existence has become environmentally hazardous - primarily due to the formation and accumulation of huge amounts of production and consumption waste. According to the Ukrainian national waste management strategy, the volume of municipal solid waste (MSW) in 2016 was about 11 million tons [1]. The average annual waste generation rate in Ukraine is 250-300 kilograms per person and it tends to grow.

Landfilling remains the dominant method of waste disposal in our country. Disposal of waste at landfills results in the concentration of a significant amount of pollutants on a limited area for a long time. As a rule, such areas are characterized by a high degree of emission of pollutants into the environment. The problem of municipal solid waste is its quantity and composition, which has changed from predominantly organic to nonbiodegradable waste in recent years (Fig. 1) [2]. The amount of plastic, aluminum, paper and glass discarded by the citizens is increasing $[3,4]$.

The negative environmental impact of waste can be reduced by the removal and recycling of secondary raw materials, however, the level of utilization of such waste remains low [5].

The problem of the negative environmental impact is fully related to such component of MSW as cullet. Along with the improvement of MSW processing technologies, it should be noted that cullet is still one of the most heavily recycled components. Due to the complexity of recycling, the amount of cullet in the environment continues to grow. As a result of significant volumes of non-recycled glass, the area of the land removed from economic turnover under MSW landfills grows every year. The process of washing individual components out of cullet under the influence of precipitation leads to the contamination of soils and groundwater. Cullet dust is carried by the wind and has a negative impact on the air and soil near the landfills. To control the situation, it is necessary to predict the accumulation of waste.

The main volume of glass waste is generated by various types of glass containers. From the environmental point of view, glass is considered to be rather difficult to recycle. Organic waste can decompose completely within 1-3 years, polymeric materials decompose after 5-20 years, while glass can retain its properties for more than 100 years [6]. Glass recycling can make it possible to reduce waste volumes and conserve about 10000 hectares of land annually [7].

In other parts of the world, the share of recycled waste varies widely enough. For example, the USA recycles $23-25 \%$ of household waste, the European Union - 32-36 \%, Japan - $20 \%$. High levels of recycling are typical for such kinds of waste as ferrous metal scrap (more than $88 \%$ ), cullet $(84 \%)$, waste paper $(65 \%)$, textile waste $(41 \%)$; low levels - for polymeric waste $(8.3 \%)$, waste tires $(4.7 \%)$ [8]. 

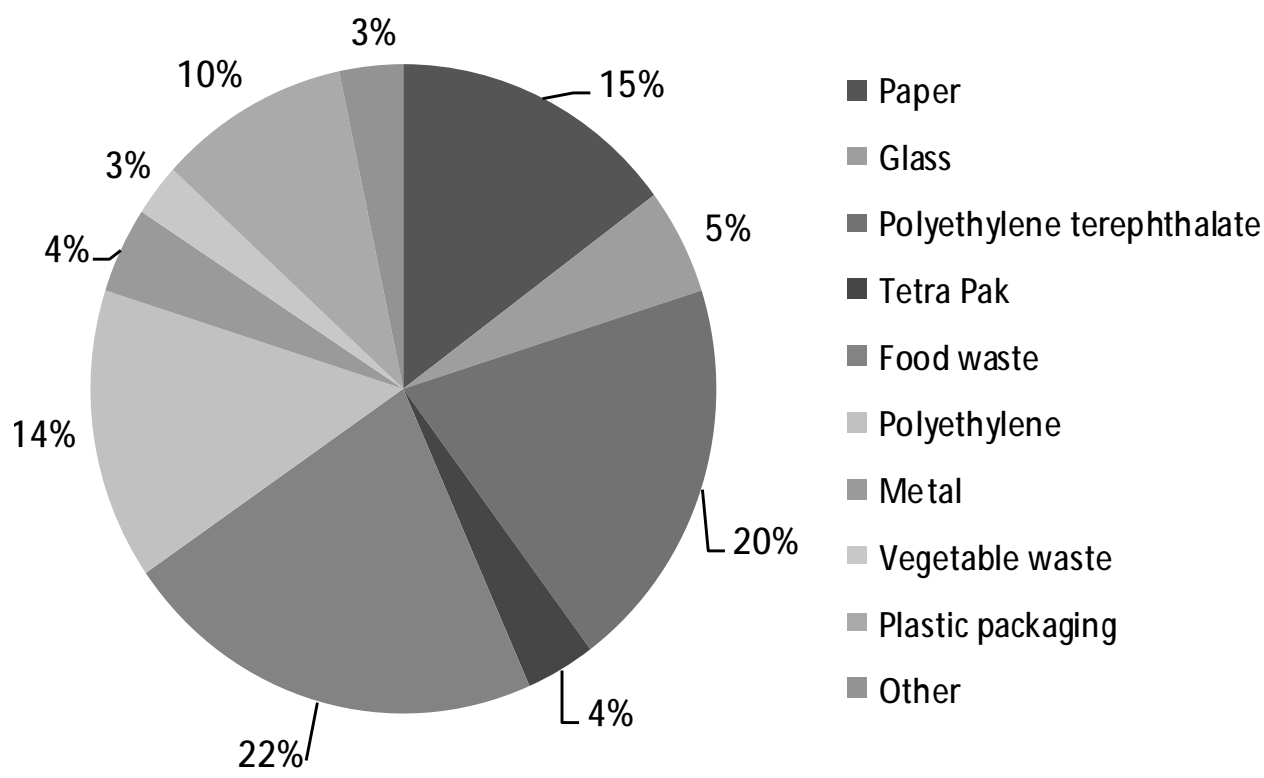

Fig. 1. Morphological composition by waste categories

Glass products hold a special place in the circular economy, as glass has been defined a 'permanent material', since it is totally and endlessly recycled without any degradation of its properties [9]. The first reference to "permanent materials" in the European legislation dates back to 2012, in the resolution on a resourceefficient Europe [10].

Cullet recycling plays a priority role in saving resources and primary raw materials at enterprises, as well as contributes to the preservation of the environment. Since cullet is a high quality raw material, its use in glass production leads to :

- Reduction of primary raw material consumption (quartz sand, soda, dolomite, etc.),

- Reduction of $\mathrm{SO}_{2}$ emissions from the melting of raw materials,

- Extension of furnace service life up to $30 \%$ and increase in its capacity, due to the lower temperature and reduced melting time,

- Decrease in fuel consumption, which also helps to reduce $\mathrm{NO}_{\mathrm{x}}$ and $\mathrm{SO}_{2}$ emissions into the environment;

- Preservation of land through collection and recycling instead of burial;

- $100 \%$ recycling [11-14]

According to the data of the State Statistics Service of Ukraine (Table 1), there has been an increase in the generation of glass waste in recent years, but its recycling or removal remain insignificant.

As a result of significant volumes of non-recycled glass, the area of land removed from the economic turnover for solid domestic waste (MSW) landfills grows every year. The process of washing individual components out of cullet under the influence of precipitation leads to the contamination of groundwater
[15]. All the aforesaid indicates the need for the assessment of the environmental impact of cullet in two directions - removal of territories from the turnover due to the accumulation of waste, and contamination of ground waters and soils upon the washing out of $\mathrm{Na}^{+}$ions.

Table 1

The volume of formation of glass waste and waste management, thousand tons

\begin{tabular}{|c|c|c|c|c|c|}
\hline Year of formation & 2013 & 2014 & 2015 & 2016 & 2017 \\
\hline Waste generation & 40.1 & 23.5 & 22.3 & 25.8 & 34.3 \\
\hline Waste utilization & 14 & 1.8 & 2.1 & 1.8 & 3.4 \\
\hline $\begin{array}{l}\text { Waste removal to } \\
\text { designated places }\end{array}$ & 0.1 & 0.3 & 0.3 & 1.0 & 0.3 \\
\hline
\end{tabular}

\section{Material and methods}

\subsection{Mathematical model of glass waste accumulation}

Effective municipal solid waste (MSW) management requires the prediction of waste accumulation. Therefore, in order to control the situation with cullet, a mathematical model of cullet accumulation has been developed.

The mathematical model has been developed in a MatLab package with the use of a linear and multiple regression.

For the linear regression, we first of all find the parameters of the model that provides for waste generation in the subsequent years.

$$
\hat{g}_{x}=a+b * x
$$

We solve the system of normal equations relative to $\mathrm{a}$ and $\mathrm{b}$ and find the standard deviations $\sigma(\mathrm{x})=1.414$; 
$\sigma(\mathrm{y})=4.909$ and dispersion: $\sigma^{2}(\mathrm{x})=2 ; \sigma^{2}(\mathrm{y})=24.096$. Based on the calculation of parameters of the regression equation: $b=3.07 ; a=-6160.85$ the model takes the form:

$$
\mathrm{y}=-6160.85+3.07 \cdot \text { year }
$$

To assess the adequacy of the model, an average approximation error was calculated: $\bar{A}=8.44 \%$. To reduce the error, it is necessary to add more experimental points. To further evaluate the model, we run an F-test. It lies in checking the $\mathrm{H}_{0}$ hypothesis about the statistical insignificance of the regression equation and the strength of the relationship index.

$$
F_{\text {fact }}=\frac{r^{2}}{1-r^{2}} * \frac{(n-m-1)}{m}
$$

where $\mathrm{n}$ is the number of experiments; $\mathrm{m}$ is the number of fixed variables; $r$ is a linear pair correlation coefficient. By substituting the numerical values we get $\mathrm{F}_{\text {fact }}=10.779$. The tabular value of Fisher's criterion is 6.61. Since $\mathrm{F}_{\text {table }}<\mathrm{F}_{\text {fact }}$, we conclude that the $\mathrm{H}_{0}$ hypothesis of the random nature of the characteristics being evaluated is rejected and their statistical significance and reliability are recognized. The obtained estimates of the regression equation allow using it for prediction.

To construct the model using the multiple regression equation, the data from Table 1 was used, where waste disposal is (a) data vector, removal to designated locations is (b) data vector, year is (c) data vector, $y$ is the amount of waste.

At the first stage, the vector of regression coefficient estimations is determined. According to the least square method, the vector is obtained from the expression:

$$
k=\left(X^{T} X\right)^{-1} X^{T} Y
$$

After multiplying the matrices $X^{T} X, X^{T} Y,\left(X^{T} X\right)^{-1}$ we have calculated the regression equation coefficients by formula 4, and obtained: $\mathrm{k}_{1}=1.608952 \cdot 10^{4}$; $\mathrm{k}_{2}=2.135684 \cdot 10^{1} ; \mathrm{k}_{3}=2.521962 \cdot 10^{1} ; \mathrm{k}_{4}=-7.999756$.

Thus, the model takes the form:

$$
y=k_{1}+k_{2} \cdot a+k_{3} \cdot b+k_{4} \cdot c .
$$

Based on the model obtained, we construct a graph of the regression equation of waste accumulation (Fig. 2).

To evaluate the model, we have calculated the standard deviation:

$$
\sigma=\sqrt{y^{2}}=1.855759
$$

The error is 3.160029. The strength of the influence of factors on the result is evaluated by the index of multiple correlation, calculated as follows:

$$
R=\sqrt{1-\frac{\sum\left(y_{i}-y_{x}\right)^{2}}{\sum\left(y_{i}-\bar{y}\right)^{2}}}=9.999306 \cdot 10^{-1}
$$

The connection between $\mathrm{Y}$ and $\mathrm{X}$ is strong. The determination coefficient is 0.9998612 . That is, in $99 \%$ of cases of a change in $\mathrm{x}$ results in a change in $\mathrm{y}$. In other words, the accuracy of the regression equation selection is high.

The tabular value of the Student's criterion is less than the calculated one. This means that the correlation coefficient is statistically significant. For the obtained model $F_{\text {table }}<F_{\text {fact }}$, i.e. the determination coefficient is statistically significant and the regression equation is statistically reliable.

The mathematical model of the multiple regression has a smaller error than the pair model due to the addition of experimental points.

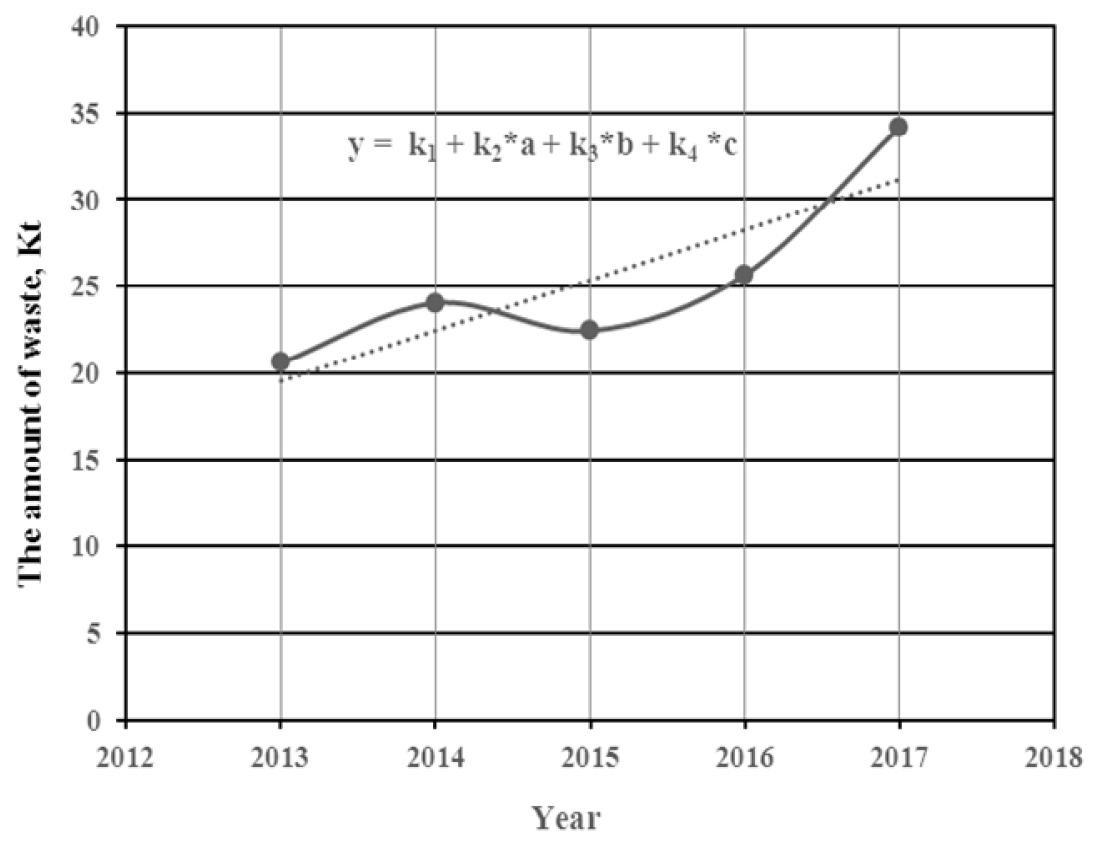

Fig. 2. Regression equation for the amount of glass waste 


\subsection{Experiments}

To determine the amount of $\mathrm{NaOH}$ alkali that is washed out of glass, experimental studies were carried out.

In order to achieve the conditions of the experiment closer to those of formation and storage at MSW landfills, we have used a mix of window glass, green bottle glass, brown and white glass in the ratio of 1: 1: 1: 1 (mass). Glass was crushed to pieces sized $\leq 0.1 \mathrm{~mm}, 0.25-1 \mathrm{~mm}$, 1-2 $\mathrm{mm}, \geq 3 \mathrm{~mm}$ and placed into distilled water at room temperature. In real conditions of MSW landfills and unauthorized landfill sites, according to the work of Mikhailenko V. V. [16], the $\mathrm{pH}$ of the surface filtrate in different points of the landfill differs from the neutral one. Therefore, the assessment of leaching of components was carried out in parallel in an acidic environment at $\mathrm{pH}=4.8$ in a buffer solution and at $\mathrm{pH}=9.2$.

$10 \mathrm{~g}$ samples of the powder were placed into a container, which was then filled with $100 \mathrm{ml}$ of a solution. In 7 and 30 days the solution was filtered and a quantitative analysis of
$\mathrm{Na}+$ content was carried out on an atomic absorption spectrophotometer $\mathrm{C}-115 \mathrm{M} 1$ in the emission mode. The analysis of the solutions to determine the concentration of $\mathrm{Na}+$ was carried out in accordance with the standard method "Mass concentration of sodium and potassium in water. Flame photometry measurement method" RD 52.24.3912008. A mixture of air-propane-butane is used as an atomizer (to produce free atoms from liquid samples).

\section{Results and discussion}

According to the obtained model, a long term forecast of glass waste accumulation for 10 years was made, the results are presented in the graph (Fig. 3).

It is evident that over time, the amount of waste at landfills will increase, leading to the alienation of territories. At the same time, the condition of soils and groundwater is deteriorating due to $\mathrm{Na}+$ leaching. This is confirmed by the experiment, the results of which are presented in Table 2 and Fig. 4.

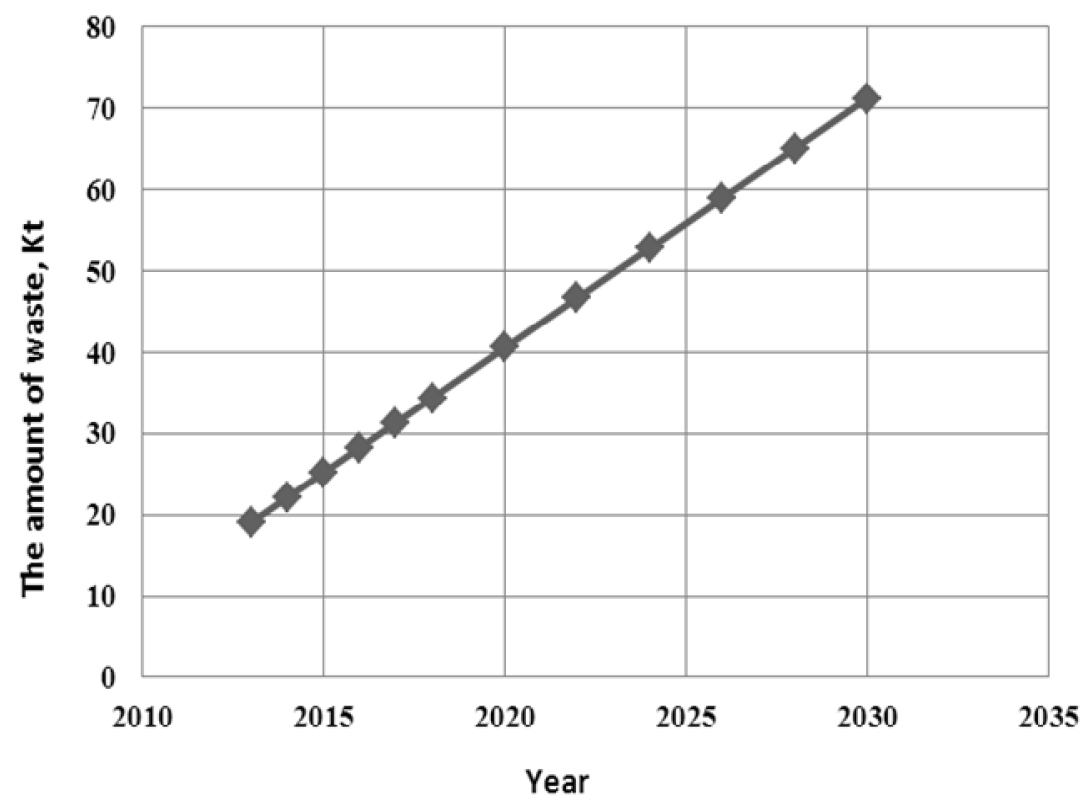

Fig. 3. Cullet accumulation forecast

Amount of sodium ions $\mathrm{Na}$ leached from the surface of unsorted glass of different fractions

\begin{tabular}{|c|c|c|c|}
\hline Type of solution & Fraction, mm & $\begin{array}{c}\text { Number of leached } \mathrm{Na}^{+} \\
\text {in } 7 \text { days } \mathrm{mg} / \mathrm{g}\end{array}$ & $\begin{array}{l}\text { Number of leached } \mathrm{Na}^{+} \\
\text {in } 30 \text { days }\end{array}$ \\
\hline \multirow[t]{4}{*}{ Neutral environment } & $\leq 0.1$ & 0.263 & 0.559 \\
\hline & $0.25-1$ & 0.057 & 0.098 \\
\hline & $1-2$ & 0.022 & 0.033 \\
\hline & $\geq 3$ & 0.008 & 0.015 \\
\hline \multirow{4}{*}{$\begin{array}{c}\text { Acidic environment } \\
\mathrm{pH}=4,8\end{array}$} & $\leq 0.1$ & 0.375 & 0.849 \\
\hline & $0.25-1$ & 0.065 & 0.130 \\
\hline & $1-2$ & 0.031 & 0.037 \\
\hline & $\geq 3$ & 0.011 & 0.015 \\
\hline \multirow{4}{*}{$\begin{array}{l}\text { Alkaline environment } \\
\mathrm{pH}=9,2\end{array}$} & $\leq 0.1$ & 0.197 & 0.318 \\
\hline & $0.25-1$ & 0.049 & 0.065 \\
\hline & $1-2$ & 0.025 & 0.029 \\
\hline & $\geq 3$ & 0.006 & 0.009 \\
\hline
\end{tabular}


This data shows that acid is more intense than water or alkaline media in terms of leaching out of sodium ions, and equilibrium conditions occur faster. The degree of leaching depends on the acidity of the environment, so in real-world biogeocenosis conditions, the number of ions that are leached out may differ significantly from the values obtained, which increases the negative impact of cullet. Thus, an inherent feature of silicate glass is its ability to interact with water and release sodium $\mathrm{Na}^{+}$ions into the aquatic environment as a result of such interaction. As a result of ion exchange, a film of hydrated silicon oxide is produced on the glass surface. It should be noted that freshly deposited hydrated silicon oxide is always considered as a fairly active chemical compound, so its presence on the surface of glass can serve as a basis for engaging glass into various chemical processes. If we consider high dispersion glass, its specific surface, available for ion exchange, and therefore for chemical processes, increases proportionally to the size of the particles, and the possibility of targeted application of this interaction increases greatly.

It can be assumed that the main role in the possibility of leaching sodium $\mathrm{Na}^{+}$ions from the glass surface is played by the microstructure of the material, which is formed in the processes of melting and annealing. Leaching rate and depth depend significantly on acid concentration in the solution.

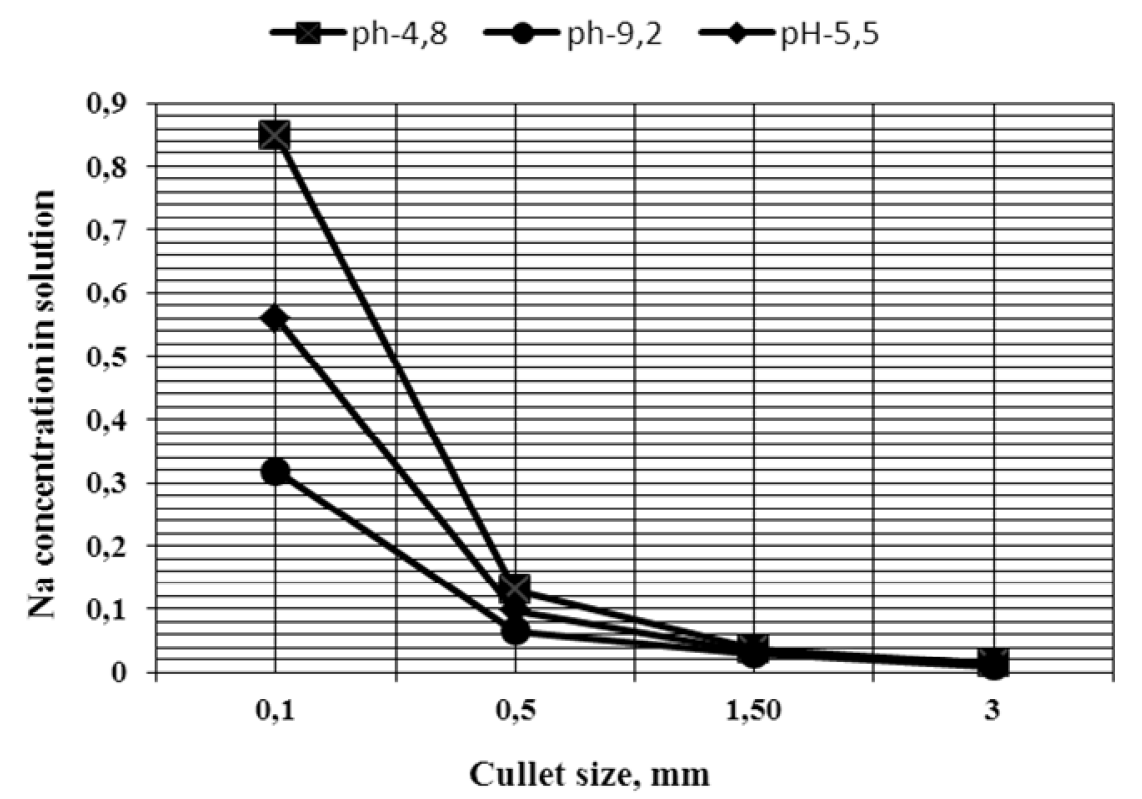

Fig. 4. Dependence of $\mathrm{Na}^{+}$leaching on cullet size and $\mathrm{pH}$ solution

\section{Conclusions}

As a result of experiments it was established that characteristic and specific property of the cullet is leaching or ion-exchange properties of the material surface. Moreover, glass grinding leads to a visible growth of quantitative indicators of ion exchange. This fact allows us to refer ion-exchange properties of glass waste to the specific properties of this type of waste along with such property as pyroplasticity.

Long-term storage of cullet and glass packaging waste at MSW landfills under the influence of precipitation will lead to continuous release of alkali into the environment until the threshold value is reached. Unauthorized landfills and bottles scattered outdoors in recreational areas are particularly dangerous. The costs of disposal of such landfills are increased due to the need for additional soil remediation, and, in the long run, the properties of soils in recreational areas where regular garbage collection is not provided may change to undesirable for the growth of traditional plant species.

In connection with the above, the issues of complex processing of cullet and glass container waste are relevant not only in terms of resource saving, reduction of energy consumption for the production of consumer products, but also in terms of reducing the negative environmental impact of the storage of cullet and glass container waste at MSW landfills.

\section{References}

[1] Rozporjadzennja kabinetu ministriv Ukrainy vid 08.11.2017 No. 820-p. Oficijnyj visnyk Ukrainy. 2017. № 94. St. 2859. (in Ukrainian)

[2] Hurets L. L., Kotolevets A. S., Kotova I. I.: Znyzennja rivnja technohennoho navantazennja na dovkillja pid cas vykorystannja vidhodiv skla. Naukovo-praktycnyj zurnal 
ekolohicni nauky, 2018, 4(23): 41-45. (in Ukrainian) https://doi.org/10.32846/2306-9716-2018-4-23-9.

[3] Abdel-Shafya H., Mansourb S. M.: Solid waste issue: Sources, composition, disposal, recycling, and valorization. Egyptian Journal of Petroleum, 2018, 27 (4): 275-1290. https://doi.org/10.1016/j.ejpe.2018.07.003.

[4] Padmalatha N. A., Prabhish S.: Impact of recycling in a glass industry: a project management study. BIMS International Journal of Social Science Research, 2016: $50-61$.

[5] European Commission. Being wise with waste: the EU's approach to waste management. Luxembourg: Publications Office of the European Union. P. 16. doi 10.2779/93543

[6] Chung S., Elrahman M., Sikora P. et al.: Evaluation of the Effects of Crushed and Expanded Waste Glass Aggregates on the Material Properties of Lightweight Concrete Using Image-Based Approaches. Journal of Materials, 2017, 10(12). doi: 10.3390/ma10121354.

[7] Ling T., Poon C., Wong H.: Management and recycling of waste glass in concrete products: Current situations in Hong Kong. Journal of Resources, Conservation and Recycling, 2013: 25-31. doi: 10.1016/j.resconrec. 2012.10.006

[8] Ivantsova E. A.: Problemyi i perspektivyi upravleniya tverdyimi byitovyimi othodami. Vesti Volgogradskogo gosudarstvennogo universiteta, 2016, 2(35): 148-159. (in Russian) http://dx.doi.org/10.15688/jvolsu3.2016.2.15

[9] Testa M., Malandrino O., Sessa M. R. et al.: Long-Term Sustainability from the Perspective of Cullet Recycling in the Container Glass Industry: Evidence from Italy.
Journal of Sustainability, 2017，9: 19. doi:10.3390/ su9101752

[10] Tiozzo S., Favaro N.: Permanent Materials in the framework of the Circular Economy concept: review of existing literature and definitions, and classification of glass as a Permanent Material. The Glass Research Center, 2016 Report N. 136480.

[11] Supino S., Malandrino O., Testa M., Sica D.: Sustainability in the EU cement industry: the Italian and German experiences. Journal of Cleaner Production, 2016. doi: 10.1016/j.jclepro.2015.09.022

[12] Kovacec M., Pilipovic A., Stefanic N.: Impact of Glass Cullet on the Consumption of Energy and Environment in the Production of Glass Packaging Material. Recent Researches in Chemistry, Biology, Environment and Culture. Monteux, Switzerland, 2011.

[13] Imteaz M., Ali M., Arulrajah, A.: Possible environmental impacts of recycled glass used as a pavement base material. Journal of Waste Management and Research, 2012, 30(9), 917-921. doi: 10.1177/0734242X12448512

[14] Tsai C. L., Krogmann U.: Material Flows and Energy Analysis of Glass Containers Discarded in New Jersey, USA. Journal of industrial ecology, 2013, 17(129), 129-142. DOI: 10.1111/j.1530-9290.2012.00509.x

[15] Jain V. Chemical durability of nuclear waste glasses-a review. Journal of Materials Science \& Technology. https://www.nrc.gov/docs/ML0613/ML061310303.pdf

[16] Mihaylenko V. V. Povyishenie ekologicheskoy bezopasnosti vodnyih ob'ektov $\mathrm{v}$ zone vliyaniya svalok tverdyih byitovyih othodov. Harkov, 2016, 73-85. 